\title{
THE PRINCIPAL'S STRATEGY IN IMPROVING TEACHER'S PROFESSIONALISM ON UNDERDEVELOPED AREA
}

\author{
Nur Hasanah \\ Doctorate Program of Educational Management, State \\ University of Malang, Indonesia \\ anureel@yahoo.com
}

\author{
Kusmintardjo \\ Department of Educational Management \\ State University of Malang, Indonesia \\ kustar_um@yahoo.co.id
}

\begin{abstract}
Professionals are teachers who effectively master the subject matter and skills and have good teaching skills. Effective teachers have good teaching strategies and are supported by goal-setting methods, teaching design and classroom management. They know how to motivate, communicate and get along effectively with their students from diverse cultural backgrounds. These teachers also understand how to use appropriate technology in the classroom. The problem raised in this research concerns with the strategy in improving the teacher's professionalism on underdeveloped at SMP Al Hilaal Haya, Central Maluku District. The type of this research was descriptive qualitative. The study was conducted at SMP Al Hilaal Haya, Tehoru regency, Central Maluku District, Maluku Province. The data obtained from observation, interview, and documentation, were then analyzed by using the stages of data reduction, data assessment, and data conclusion (verification). The result of the research showed that there some principal's strategy in improving teacher's professionalism in underdevelped area at SMP Al Hilaal Haya. They are a) sending teachers on trainings and seminars; b) Motivating teachers as motivation from school principal serves as a passion for teachers to do improvement in educational innovation; and c) conducting a supervision at SMP Al Hilaal Haya for at least each semester
\end{abstract}

Keywords: strategy, professionalism, underdeveloped area

\section{INTRODUCTION}

Being a professional teacher in an underdeveloped area requires a teacher to have not only professional competence or the expertise in the field of study but a teacher also need to have a social competence. It means that the teachers should be the role models for their students because essentially the life in underdeveloped area is more likely to preserve the values of local wisdom. The mastery of social competence is important as teachers are part of the community that is as consumers of education. In fact, the efforts that have been done so far in developing teacher's professions which is related to the effort in strengthening social competence seem to yield very relatively limited result as most teachers tend to focus on the development of their pedagogic and professional competencies. In reality, in teacher training, the indepth subject matter tends to be focused more in the effort in strengthening teachers' pedagogical and professional competence. On the other hand, the development and the effort in strengthening teacher's social competence is then laid on each individuals. With regard to this condition, there is a need to have a systematic, patterned and sustainable social enhancement strategies. The teachers being discussed here refewr to the teachers who live in underdeveloped area . Thus the guidance of teacher competence in underdeveloped area must be considered well because teachers are the pillars of education supporting the success of education by integrating the values of local wisdom (Rahmawati, 2012: 1).

Based on the results of previous research conducted by [5] in India, it was stated that a progress of a country depends on the quality of teachers. When teachers no longer think about the process of learning development then leaders will no longer evaluate teacher's performance. So, the learning process will not run properly, the graduates produced will not be in accordance with the objectives. Similarly, a research by Alsrhid [1] stated that teachers are leaders in learning who transfer experience and information (knowledge), and direct the behavior of students. Teachers play an important role in preparing students to become good citizens and become agents of social change.

Other research results were found by [3] regarding the implementation of local curriculumbased curriculum development policy at three vocational High schools (VHS) in Manggarai district of East Nusa Tenggara. The research findings are 1) extra curricular program used in VHS is an integrated curriculum model which is done by synergizing between national education curriculum (national education department), local cultural curriculum, and local content curriculum with fullday school system. 2) the curriculum is based on local cultural values as spirit and motivation so that learning process conducted is more humanist, holistic, effective and meaningful according to the characteristics of society around that VHS. 3) the process and stages of the implementation of local culture-based curriculum policy start from the smallest unit of teachers in the field of study after involving the principal, school-level meetings, all stakeholders, teachers, heads of vocational schools, foundations, school committees, and Businessman.

One of the examples in the case happened in one of the educational institutions in Central Maluku District which were previously observed by the researcher. The observation conducted in school namely SMP Al Hilaal Haya revealed the crucial problems faced in general, that is first, the personality of teachers who are still unstable. This can be proven by teacher's attitude in punishing their students by using violence. Thus, this kind of teacher is difficult to 
be an example for their students. Second, the ability of teachers as a part of society is still low. For example, teachers are not able to write scientific papers as part of communication with the community and there are still teachers who have not been able to solve problems when there is conflict between communities. Third, there are still teachers who seem apathetic to their duties as an educator, mentor, teacher and so on. With regard to local wisdom, people in Central Maluku district consider teachers as the highest professions so that teachers in the village are highly respected and honored. Therefore, when the teachers do not have a commitment, responsibility and competence in their field, they are considered as individuals who have a moral burden on their relationship with God, society and environment. The problem faced here is teachers need a kind of training to add their insight and improve their skills while maintaining the values of local wisdom although they live in underdeveloped areas

\section{Research problem}

The focus of this research is how to improve The principal's efforts in improving teacher professionalism in SMP Al Hilaal Central Maluku District?

\section{Research objective}

The purpose of this study is to determine the improvement of principal's efforts in improving teacher professionalism in SMP Al Hilaal Central Maluku District

\section{METHODS}

\section{Research Desing and approach}

This research was conducted in order to find the answer to the problem as formulated in the focus of research related to the improvement of teacher's social competence by integrating the value of local wisdom. The approach used in this research was qualitative approach that is a research approach that tries to construct reality and understand its meaning, by paying attention to process, event and authenticity [7].

The research design used by the researcher was an analytical study, that is a centralized strategic study to provide a dynamic understanding with a single background covering a single case. The analysis study is: a detailed examination of one setting, or one particular event.

\section{Research location}

The reserach locations site were SMP Al Hilaal Haya of Central Maluku District Maluku Province.

\section{Data source}

The data source in this research was the subjects in which the data were obtained, using the snowball sampling technique in tracing information to key informants and additional informants associated with the focus of this research. The data sources of this research were principals, teachers, and community leaders. The recording of primary data sources through participatory interviews and observations was the result of a combined effort of viewing, hearing, and inquiring activities. Interviews conducted by the researcher is an open interview which its purpose is deliberately known by the informants.

\section{Data Collection procedure}

Ulfatin, mentioned that there are several data collection techniques used in qualitative research. The techniques commonly used in qualitative research are: (1) in-depth interviews; (2) observation of participation; And (3) document analysis ". Those three techniques were used in this research and the implementation of the three data collection techniques refers to the instruments prepared by the researcher.

\section{Data Analysis}

Data analysis is the most important step in the research activity. In qualitative research, analysis is an activity performed at the time of data collection and after all the data collected, by tracing, organizing, sorting, synthesizing, and reviewing to find patterns, interprete and present the meaning of phenomenon. The data analysis by Bogdan and Biklen is defined as a systematic process for reviewing and collecting interview transcripts, field notes, documentation, and other matters to deepen the understanding of the research focus [2].

The Data analysis used in this research is interactive model analysis technique developed by Miles and Huberman [4].

\section{RESULTS AND DISCUSSION}

The principal did some effort in improving the professionalism of teachers by implementing some strategies so it can support his leadership tasks to run effectively. The followings are the efforts and the strategies of Junior High School principal of Al Hilaal Haya in improving teacher professionalism.

\section{Sending teachers to trainings and seminars}

Teacher Education and Training Activities (PPTG) is one of the training activities that can be followed by teachers in the effort of enhancing their personal and sosial competences. This training enables education personnel to respond to changes and demands in the development of science and technology and community progress, including changes in the micro-education and learning system.

With all the shortcomings found at SMP Al Hilaal Haya, it was proven that the principal does not make them as obstacles to improve his school . that is why, the principal often sends his teachers to trainings, seminar on education, and to Teacher Education and Training Activities (PPG).

\section{Motivating teachers}

In improving the professional competence of teachers, principalencourage $s$ teachers to be creative and innovative by taking several approaches that should be done by teachers and staff. The approaches are done by familiarizing himself with the teacher, such as visiting the teacher's room. From the results of interviews, it was found out that the principal establishes good relationships with teachers and staff. 
This attitude becomes the motivation for teachers and staffs as they will feel that the principal do really care about them. Furthermore, it was also found out that the principal will not be reluctant to discuss problems his staffs encouter.

As a leader who is responsible for the achievement of the goal in education, the principal has the right strategy to provide motivation to his educators in performing various tasks and functions. The strategies are:

a. Providing adequate facilities and insfrastructure Supported by adequate facilities and insfrastructure are the expectations of all schools, including in SMP Al Hilaal Haya. This school has great hopes for having adequate facilities and infrastructure even though the reality is far from expectation. But the principal tries to improve the existing facilities, so that the teachers feel comfortable in teaching. For example, if the headmaster gets the report that the class is leaking that he will immediately looks for people to fix the problem.

\section{b. Discipline}

SMP Al Hilaal Haya prioritizes the discipline both for students and teachers. Discipline is started by the principal himself as he provides the role model for his staffs and students. From the observation done by the researcher, it was found out that the principal arrives in time that is at 6.30 am that is earlier compared to other teachers and by the time the school ends, he will go home late . Actually, the school hour starts at 07.30 and ends at 1.20 P.M , but the principal has a policy that teachers must come at 07.00 a.m before the school starts. As the principal continously gives good role model, the teachers become diligent and they are reluctant to come late.

\section{c. Supervision}

Supervision is a planned coaching activity to assist teachers and other school staffs in performing their work effectively. Supervision as one of the main functions in educational administration, is not only the task of the supervisors, but also the task of the principal, teachers, and the school staffs. The supervision at SMP Al Hilaal Haya was done by the principal assisted by the vice principal of the curriculum section and this was done every semester.

\section{CONCLUSION AND RECOMMENDATION \\ 1. Conclusion}

SMP Al Hilaal Haya certainly requires a professional teacher in its process of teaching and learning, because the teacher is a person who is responsible for delivering students have high scientific quality. The ability of teachers as educators in terms of personal, social, and professional, should be paid attention because basically the teacher as an educational staff is a field worker who carry out education and they also serve as the spearhead of educational success. The principal's efforts to improve the professionalism of teachers in underdeveloped areas in SMP Al Hilaal Haya are as followa) sending teachers into a training, pragrams and seminars. Promoting discipline for both students and teachers. And motivating teachers to pursue their profesionalism.

\section{Recommendation}

Based on the findings of this research, the researchers has some recommendations as follow:

a. Principal is expected to further improve the professionalism of teachers at schools. As science and technology continues to grow, the teaching and learning process should not be conducted in such monotonous way so that qualified graduates can be produced.

b. Teachers are expected to be more active in adapting with the development of science and technology by improving their quality one of which can be done by making a good preparation before teaching in class and making a creative classroom environment despite the school limitations particularly in underdeveloped area.

\section{REFERENCES}

[1] Alsrhid, M. 2012, Analytical study of the professional qualifications of the teacher in the Arab World. Journal of Education and Practice, 3(13): 17-38.

[2] Bogdan, R. C., dan Biklen, S. K. 1982. Qualitative Research for Education: An Introduction to Theory and Methods. London: Allyn and Bacon, Inc.

[3] Majir, A. 2011. Implementasi Kebijakan Pengembangan Kurikulum Ekstra Kurikuler Berbasis Budaya Lokal (Studi Multikasus Pada 3 SMK di Kabupaten Manggarai. Nusa Tenggara Timur). Dissertation. Malang: State University of Malang.

[4] Miles, M. B., dan Huberman, A. M. 1992. Analisis DataKualitatif: Buku Sumber Tentang Metode-Metode Baru. Jakarta: UI Press.

[5] Parves. M., \& Shakir, M, 2013, Attitudes of Prospective Teachers towards Teaching Profession. Journal of Education and Practice, 4(10): 172-178.

[6] Ruslan. 2013. Supervisi Pengajaran Kepala Sekolah Berbasis Kearifan Lokal dalam Meningkatkan Profesionalisme Guru (Studi Multisitus pada SMAN 1 Kota Bima, SMAN 1 Bolo Kabupatena Bima, dan SMAN 1 Doтри Kabupaten Doumpu). Dissertation. Malang: State University of Malang.

[7] Somantri, G. R. 2005. Memahami Metode Kualitatif. Jurnal Makara, Sosial Humaniora, 9(2), 17-26.

[8] Ulfatin, N. 2013, Hambatan Kesempatan Guru Wanita Menjadi Kepala Sekolah Ditinjau dari Segi Sosial Kultural. Dissertation. Malang: State University of Malang. 